\title{
Three-Tier Federative Structure and Local Government Autonomy in Brazil and Nigeria
}

\author{
Okechukwu Marcellus Ikeanyibe, $\mathrm{PhD}$ \\ Department of Public Administration And Local Government \\ University of Nigeria, Nsukka \\ Email: okey.ikeanyibe@unn.edu.ng
}

\section{Doi:10.5901/mjss.2014.v5n15p559}

\begin{abstract}
This paper examines the nature of three tier federative structure of Brazil and Nigeria and the reasons for the failure of the model to guarantee local government autonomy as envisaged by the design. It is found that the two countries exhibit divergence in the manner of constitutionalisation, which also provides difference in degree of autonomy enjoyed by the local government- where the constitution provides powers and rights of local government directly or whether it seeks to achieve these through the laws of other governmental levels. In Nigeria the structure has not lifted the local government beyond an embedded system in a dual federal structure in which the states merely deal with local governments as appendages rather than as separate tier of government. In Brazil, the structure provides relative political and fiscal autonomy, but also inhibits smooth fiscal control by Federal government that makes constitutional changes more frequent. In both experience, it is seen that federalization through constitutionalism still has its limits.
\end{abstract}

Keywords: three tier federative structure, Brazil, Nigeria, Local government autonomy, constitutionalism.

\section{Introduction}

Federalism was originally conceived as sharing of political powers between two levels of government. Nico Steytler (2005), remarks that the first model federal constitutions of the modern era did not include local government as an order of government; thus, making local government a creature of state/regional/provincial power. Today, the concept of federalism has gradually diffused to include various categories of decentralisation arrangement that involves not just two levels of government (the union and the federating units - states, cantons, regions, provinces etc)-but also the local governmental level or municipalities. The three tier federal structure obviously places new demands on the theory and practice of federalism (Steytler, 2005). It is no more the issue of how power is shared between the federation and the second level federating units but how the local government powers, functions, financing etc. should be given some constitutional leverage and protection that are beyond the wishes and caprices of the higher tiers of government.

The Constitutions of Germany (1949), Spain (1978), Nigeria (1979/1999), Brazil (1988), India (1992), South Africa (1996) to mention a few have all made constitutional provisions that aim at ensuring significant decentralization and local autonomy. Nigeria and Brazil are considered in this study. Despite enormous differences that can be counted, the two countries share some common features that provide grounds for comparative studies of their model of federalism and local government systems. Both countries practice the federal presidential system of government modeled after the United States' system. Both countries have experienced autocratic regimes like military governments that have tended to concentrate power at the centre. The two countries also constitute enormous geographical, political and social disparities that require extensive power dispersion to the periphery, thus, leading to tension between centralism and regional desires to avoid domination by the centre. The two countries were formed by colonial powers as a unitary system but later considered the federal structure as a ploy to balance power between centralizing federal forces and local prerogatives for autonomy.

The greatest diversity factor in Brazil seems to be what Montero (2010) describes as the landed oligarchy or powerful landowning elites who have developed strong ties with their peasant clients. Sodaro et al (2001) also refer to the existence of distinct regions with different political and economic histories. Serra and Afonso (2007) observe that the Federation was created in 1891 as a response to regional differences and administrative needs spanning a continentsized land area. To ensure effective governance in such a vast territory which is rated as the fifth largest country in the world and occupies about two-thirds of South American continent requires a high degree of centralization and decentralization for as Sodaro, et. al. (2001) argue, one challenge of any national government in such vast territory is to accommodate regional differences as well as institute a strong centralizing force that can weld the pluralism together as 
one country.

Though Nigeria is not in any dimension comparable to the Brazilian landmass, it exhibits substantial centripetal forces that require effective decentralization to satisfy local desire for autonomy. Ikeanyibe (2008:31-32) has noted that 'in Nigeria where ethnic nationalities are inclined towards self-determination, there is no gainsaying that the local government as constitutionally recognized would serve to grant some level of political autonomy to small ethnic nationalities.' Nigeria has over 300 ethnic nationalities.

The importance of federalism and the constitutional recognition of local government as a third tier government in designing the two countries' political structure are therefore a ploy to balance centrifugal and centripetal forces. The key question remains whether this approach has ensured adequate autonomy for the two countries' local government system. As Gamper (2005) queried, can the local government level or municipalities be equal third partners as units in a federal contract? Have the de jure constitutional provision and protection of basic powers, functions, financing of local governments de facto ensure adequate autonomy for the local government system of Brazil and Nigeria? This paper is an attempt to examine this ever recurrent decentralization poser in the case of Brazil and Nigeria. More specifically, the guiding research questions are:

$>$ What are the special features of the three tier federative structure of Brazil and Nigeria?

> To what extent has this model facilitated the institutionalization of significant autonomy for the two countries' local government system?

$>$ What are the lessons drivable from the model and its practices in both countries for the theory and practice of federalism and improved local government administration?

The paper is mainly documentary and descriptive drawing largely from constitutional provisions on local government in both countries and existing scholarship on federalism, local government autonomy and intergovernmental relations.

\section{Conceptualizing Federalism and the Import for Autonomy of Federating Units}

The word federation is enlarged to describe various kinds of state organisations. This invariably leads to various kinds of theorisation about the process, structure, and the overall objective of the principle of federalism. The word derives from Latin foedus meaning pact, alliance, covenant, an arrangement entered into voluntarily and implying a degree of mutual trust and duration (Dosenrode, 2010). Obianyo (2005) notes that even though federalism has attracted a wide variety of meanings and definitions, it has not lost its essential characteristics or content, which in the view of Wheare (1964), is the method of dividing powers of government in a state so that general and regional governments are each within a sphere, coordinate and independent. It is the idea of self-rule and shared rule, which Wheare (1964) and Elazar (1987) regard as the federal principle. For Wheare, (1964: 35-36), the workability of the federal principle is contingent on the recognition of the dual prerequisites of federalism which according to him entails that the communities of states concerned (i.e., federating) must desire to be under a single independent government for some purposes...secondly, they must desire at the same time to retain or establish independent regional government in some matters at least.

A critical factor in the theory of federalism is how this self rule and shared rule is realised. There is also the issue of whether local governments can actually be a coordinate partner in the federal contract.

The traditional, institutional or classical theorists of federalism and indeed the first model federal constitutions depict a form of government that embodies certain institutional and constitutional features between the federating units and the federal government. This view basically rests on the importance of constitution in the formation of federations. Wheare (1964) conceives a number of principles which define a federation. These are:

$>$ The division of governmental responsibilities between levels of government;

$>$ A written constitution spelling out this division and from which federal and state authorities derive their powers;

> A judiciary independent of both levels of government that acts as an arbiter in cases where there are conflicts over the jurisdictions enumerated in (1) above;

$>$ Coordinate supremacy of the various levels each in its respective field of operation;

$>$ the citizens of the federation being concurrently under two authorities and owing loyalties to them;

$>$ the powers to amend the constitution to be exercised by both levels of government acting in cooperation;

> Financial independence of both levels of government as financial subordination makes an end of federalism.

From the above, constitutionalism is considered very significant in the allocation and protection of powers of central government and coordinate units, hence the requirement that constitutional powers of changes/amendment must be exercised by both levels of government. Also, while the institutional theory does not expressly state it, it does presume that federations are usually made up of two levels, namely, the newly formed political entity and the various units coming 
together to form the new one. Hence, most scholars of this tradition often refer to two levels of government. This is why the model is often referred to as the dual model of federalism in which each level of government, national and states (provinces, cantons, regions etc.) are supreme within her areas of responsibilities; neither level is dominant and neither level should intervene in the affairs of the other (Rosenbloom and Kravchuk, 2002).

The alternative theoretical bent in explaining federalism is that which stresses the role of the socio-political makeup of a country and the diversities within rather than power sharing. These theories basically explain federalism as a tool or instrument for managing diversity and ensuring the self-expression or the autonomy of units that are sociologically different from others within a polity. Among the foremost proponents is Livingstone (1985:22) who explains federalism as a device by which the federal qualities of a society are articulated and protected. For him,

The essential nature of federalism is to be sought for not in the shading of legal and constitutional terminology but in the forces of economic, social, political and cultural (systems) that have made the outward forms of federalism necessary... the essence of federalism lies not in the institutional or constitutional structure, but in the society itself... A federal government is merely a device by which the federal qualities of society are articulated and protected.

The sociological theory is considered monistic, integrative or functional because of its ability to recognise the dynamism of politics within a state which cannot be rigidly consitutionalised on a more permanent basis. As perceived by Friedrich (1964:2-3),

Federalism is a process rather than a design... Any particular design or pattern of competencies or jurisdictions is merely a phase, a short-run view of a continually evolving political reality. If understood as a process... it will become apparent that federalism may be operating in both the direction of integration and differentiation

Thus, despite the existence of diversity which can be sociologically enormous and may include such variables as ethnicity, race, tribe, caste, religion, language, culture that are territorially based, the state remains one but rather applies adequate policies to balance centripetal and centrifugal forces within the polity. Vandamme (2011:6) chooses to identify this with cooperative federalism. For him cooperative federalism is a system that is more organized along functional lines. Powers are dispersed but they are less sharply separated as in a dual system. Often policy that is established on the central level is executed by the federating entities.

The sociological and integrative theorists will rather prefer that constitutionalism in federations should not be such as to hamper cooperative relationship between tiers of government since federalism is a process rather than a structure (Elazar, 1987). The model apparently recognises the local government as a partner in the federal contract because of the emphasis on cooperation and principle of subsidiarity. When this recognition is extended to the institutional model to some reasonable degree, it is bound to throw up some flexibility challenges for federations. By constitutionalizing the local government system, dual federalism is further extended to three-tier or four-tier arrangement as the case may be.

Today, increasing number of countries pursue this programme in the bid to ensure guaranteed autonomy and local power devolution that goes beyond the wishes or laws of higher level governments. Chaturvedi (2006) defines autonomy as a grant of authority to a political organization within a geographical area to decide and determine its own course of action. Wolman, McManmon, Bell and Brunori (nd: 4-5) define it in relation to the local government as a system in which local government units have an important role to play in the economy and the intergovernmental system, have discretion in determining what they will do without undue constraint from higher levels of government, and have the means or capacity to do so. They prescribe what they describe as three dimensions of local government autonomy. These are (1) Local Government Importance (2) Local Government Discretion and (3) Local Government Capacity. Local Government Importance is explained in terms of the relative role of local government in the state economy and intergovernmental system. As they averred, "A local government system in which local government is free to do what it wishes but has no possibility of doing anything important does not conform to our concept of local autonomy." Local Discretion refers to "the ability of local government to engage in activities as it sees fit, free from constraints imposed by the state government", while Local Government Capacity conceptually includes a broad range of attributes, including resource sufficiency and stability, professional skills, management competence, quality of service delivery, etc. (Wolman, McManmon, Bell and Brunori, nd: 5).

It is important to point out that these aspects of local government autonomy apply to both unitary and federal states and may not require constitutional provisions. A local government system could enjoy this without constitutionalisation. The constitutional provision of powers of local governments within a federal state relatively places that power above what can ordinarily be changed by the laws made by higher order governments, and thus elevates local governments in such countries to having a stake in the federal contract in which that power cannot be tampered with unilaterally. This as well, does not seem to ensure the importance, discretion and capacity of local governments. Autonomy is therefore conceived here as the degree of being self-governing by the local government level granted by the national or federal constitution itself. It is a relative freestanding of local government to carry out functions or exercise powers in accordance with 
constitutional provisions rather than as granted by the laws of the second tier level government within which a local government exists.

Following from the above, we then operationalize the concept of local government autonomy here in terms of (1) Assigned powers of local government granted by the federal constitution itself rather than the laws of state, provincial or the second tier level governments (2) fiscal federalism that recognizes the local governments in constitutionally stipulated tax bases and fund sources, and, capacity to enjoy the above two without interference from higher level government. These features accommodate both de jure and de facto existence of local government autonomy vis-à-vis the imperatives of the federal constitutional provisions.

\section{Evaluating Local Government Autonomy in the Three-tier Federative Structures of Nigeria and Brazil}

As indicated above, local government autonomy in this paper is evaluated in terms of (1) the constitutional basis of local government powers as provided and protected by the federal constitution and (2) fiscal federalism that recognizes the local governments in constitutionally stipulated tax bases and fund sources.

\subsection{Constitutional Basis of Local Government Powers}

The issue of granting autonomy to sub national governments has a long tradition in Brazil. However, the issue of third tier status of local government is expressly stated in the Brazilian Constitution of 1988. Article 18 (Title III) of the 1988 Brazilian Constitution provides that 'the political and administrative organization of the Federative Republic of Brazil comprises the Union, the States, the Federal District and the Municipalities, all of them autonomous, as this Constitution provides.' The Constitution allocates areas of jurisdiction to the union, states and municipalities. Chapter IV is specifically on issues relating particularly to the municipalities. Article 30 specifies the powers of the municipalities to include:

i. legislate upon matters of local interest;

ii. supplement federal and state legislations where pertinent;

iii. institute and collect taxes within their jurisdiction, as well as to apply their revenues, without prejudice to the obligation of rendering accounts and publishing balance sheets within the Periods established by law:

iv. create, organize and suppress districts, with due regard for the state legislation;

v. organize and render, directly or by concession or permission, the public services of local interest, including mass-transportation, which is of essential nature;

vi. maintain, with the technical and financial cooperation of the Union and the state, programs of pre-school and elementary school education;

vii. provide, with the technical and financial cooperation of the Union and the state, health services to the population;

viii. promote, wherever pertinent, adequate territorial ordaining, by means of planning and control of use, apportionment and occupation of the urban soil;

ix. promote the protection of the local historic and cultural heritage, with due regard for federal and state legislation and supervision

Though some of these powers are also shared by other levels of government, the constitution expressly provides that the municipalities shall be governed by organic laws approved and promulgated by the Municipal Chamber (art. 29), thus indicating some level of legislative capacity.

The Brazilian Constitution is particularly detailed on the processes for electing the municipal personnel (executive and legislature) and the nature of supervision to be carried out under the law or by the prerogatives of high level government. Article 35 particularly provides that 'the state shall not intervene in its municipalities, neither the Union in the municipalities located in the Federal Territory, except when:

i. $\quad$ the funded debt is not paid for two consecutive years, without reasons of force majeure;

ii. the due accounts are not rendered, in the manner prescribed by laws

iii. the minimum required amount of the municipal revenues has not been applied in the maintenance and development of education;

iv. the Court of Justice grants a petition to ensure observance of the principles indicated in the state Constitution or to provide for the enforcement of the law, judicial order or decision.'

The details above on the Constitutional powers of the municipalities leaves little doubt about the legal status of local governments in Brazil as a clearly separate tier of government with distinctive sphere of jurisdictions. The grounds on which higher level governments could interfere in local government affairs as stipulated above are not contradictory to 
the notion of autonomy. Autonomy cannot be absolute even for a sovereign state.

For the Nigerian federation, the 1999 constitution, which does not differ significantly from the 1979 constitution that introduced the idea of third tier local government provides in various sections the nature, number and names, functions, funding and many other issues that are meant to guarantee constitutional autonomy of local governments. These include:

i. In section 1 (2) the 1999 Constitution provides that "Nigeria shall be a Federation consisting of States and a Federal Capital Territory." But in section 3(6), it also provides that "There shall be 768 Local Government Areas in Nigeria as shown in the second column of Part I of the First Schedule to this Constitution and six area councils as shown in Part II of that Schedule" making the number of local governments 774;

ii. section 7 (1) provides that the system of local government by democratically elected local government councils is under this constitutional guaranteed, and accordingly, the government of every state shall ensure their existence under a law which provides for the establishment, structure, composition, finance and functions of such councils;

iii. In 7(5), it provides that "The functions to be conferred by Law upon local government council shall include those set out in the Fourth Schedule to this Constitution."

iv. The First Schedule Part 1 gives the names of States and their constitutionally recognized local governments and Part II defines the Federal Capital Territory and lists its six Area Councils;

v. Section 8 provides a complex procedure for creating states or local government. Section 8 (3) particularly provides for a bill for a law of a House of Assembly for purpose of creating a new local government area to be passed by the National Assembly;

vi. Section 8 (5) provides that "An Act of the National Assembly passed in accordance with this section $(8,3)$ shall make consequential provisions with respect to the names and headquarters of State or Local government areas as provided in section 3 of this Constitution and in Parts I and II of the First Schedule to this Constitution" and Section 8 (6) writes: "For the purpose of enabling the National Assembly to exercise the powers conferred upon it by subsection (5) of this section, each House of Assembly shall, after the creation of more local government areas pursuant to subsection (3) of this section, make adequate returns to each House of the National Assembly

vii. The Fourth Schedule provides for the functions of the local government;

viii. The 1999 Constitution stipulates an arrangement that allows for statutory allocation of public revenue from the federation account to states and local governments (Section 7(6) declares: Subject to the provisions of this Constitution -

(a) the National Assembly shall make provisions for statutory allocation of public revenue to local government councils in the Federation; and

(b) the House of Assembly of a State shall make provisions for statutory allocation of public revenue to local government councils within the State.

(c) Section 162, the constitution provides some details about allocation to local governments thus:

(d) "Any amount standing to the credit of the Federation Account shall be distributed among the Federal and State Governments and the Local Government Councils in each State on such terms and in such manner as may be prescribed by the National Assembly."

(e) The amount standing to the credit of Local Government Councils in the Federation Account shall also be allocated to the State for the benefit of their Local Government Councils on such terms and in such manner as may be prescribed by the National Assembly.

(f) Each State shall maintain a special account to be called "State Joint Local Government Account" into which shall be paid all allocations to the Local Government Councils of the State from the Federation Account and from the Government of the State.

(g) Each State shall pay to Local Government Councils in its area of jurisdiction such proportion of its total revenue on such terms and in such manner as may be prescribed by the National Assembly.

(h) The amount standing to the credit of Local Government Councils of a State shall be distributed among the Local Government Councils of that State on such terms and in such manner as may be prescribed by the House of Assembly of the State.

Most of the provisions on local government incorporate some ambivalence. For instance, local governments are primarily to be created by state laws. The further directive of the type of local government to be created is not taken seriously by many states leading to various maneuvering to create all kinds of non-democratic local governments. Also, states go ahead to create local governments without ensuring the fulfillment of the last process of passing the bill by the National Assembly. 
Since the constitutionalisation of local governments in 1979, there have been issues about establishing elected councils as provided in the constitution, creation of new local governments outside those recognised in the constitution and releasing of revenues to the local governments. The Second Republic (1979-1983) which operated under the 1979 Constitution recorded uncountable instances of states' failures to comply with various provisions on local government. It was a period in which the local governments were most neglected, abused, politicized and marginalized in the scheme of things in Nigeria (Obikeze and Obi, 2004). Many states appointed care taker committees instead of the constitutionally provided democratically elected councils; many created local government systems unapproved by the National Assembly as contained in the constitution; virtually all interfered with the finances of local governments.

Also, since the return to democracy in 1999 in what is generally regarded as the Fourth Republic, states have not generally respected constitutional provisions on local government. Despite the provisions of the 1999 constitution in Section 7 (1), many states have continued to appoint non-democratically elected councils. Those that hold elections virtually restrict competition. Adeyemo (2005) observes that the usurpation of local government functions and revenue sources by state governments seriously erode the autonomy of the local governments. Many have also created local governments outside the number and names recognised in the constitution.

In 2004, President Olusegun Obasanjo threatened to withhold the federal allocations of some states that created new local governments. The affected states were Lagos, Ebonyi, Kastina, Niger and Nasarawa (Obianyo, 2005).While the threat made other states to quickly covert their newly created local governments to what they termed Development Centres, Lagos state government went ahead to operate her 37 newly created local governments and treated them at par with the existing 20 recognized in the federal constitution. The federal government also made its threat real by stopping the federal allocations to Lagos state local government councils pushing the state government to take the federal government to court on the matter. In its ruling on the matter in October 2004, the Supreme Court of Nigeria declared that the federal government has no power, either by executive or administrative action, to suspend or withhold for any period what so ever, the statutory allocations due and payable to Lagos state government pursuant to the provisions of section 162 (8) of the 1999 constitution. It also ruled that the action of the Lagos state in creating 37 new local governments through the Lagos state creation of New Local Government Areas Law No 5 of 2002 and its Amendment of October 2004 is constitutional but that the new local governments now amounting to 57 are inchoate until the National Assembly grants approval as provided in section 8 (5). The implication of this inchoate status is not clear since the Supreme Court did not restrain the Lagos state government from maintaining, financing or recognizing the new local government councils. Indeed, one of the Justices, Uwaifo made it obvious that the National Assembly has no basis to deny any state that has met the provisions of sections 8 (3) and (4) its constitutional powers to form new local governments and thus the approval of the National Assembly is really pro-forma, and was a foregone conclusion (cited by Aluko, 2004 as in Obianyo, 2005:189). This conflictual situation underscores many relationships of the states and the local government system.

For all intents and purposes, it is clear that basic features and powers of local governments in Brazil and Nigeria are de jure provided in their constitutions. While the Brazilian case can more clearly be seen to actually place local government on a third tier status, the Nigerian case is ambivalent and provides legal loopholes that have generated more conflicts in intergovernmental relations.

\subsection{Fiscal Federalism that recognizes the local governments in constitutionally stipulated tax bases and fund sources}

Fiscal federalism borders on the issue of decentralizing fiscal decision making powers to the sub-national governments. It has to do with the application of constitutional rules in the process of allocation, distribution, control, management and sharing of state resources; above all it is concerned with fiscal equity and financial independence among the federating units (Elekwa, 2009:2). Fiscal federalism should guarantee fiscal autonomy by providing an allocation regime that is fair, just and acceptable (Tukur, 2007). There could not be any single agreeable formula for determining what is fair, just and acceptable for every country as the index for revenue allocation. Hence, the issue of revenue allocation formula remains contentious in some federations. However, our concern here is to see the extent of recognition of local governments in the allocation of national resources and assignment of tax bases and the degree to which they are allowed to control these revenue sources.

For Brazil, the 1988 Constitution provided substantial fiscal resources and autonomy to sub national governments, including the municipalities. The provisions of article 156 reveal that Brazilian municipalities have two important sources of revenue - federal and state transfers and own internally generated revenue. A complex system of transfers which recognizes incomes raised from a locality as well as attempts at equalization in a highly unequal geographical regions are adopted by both the federal government and the states in making transfers to the municipalities. The table below shows the structure of local tax allocation after the 1988 Constitution. 
Table 1: Local taxes and constitutional transfers to the municipalities in Brazil

\begin{tabular}{|l|l|l|}
\hline Local Tax & Federal Transfers & State Transfers \\
\hline - Service tax (ISS) & $\bullet \quad 22.5 \%$ of income tax & $\bullet 25 \%$ of value-added tax (ICMS) \\
$\bullet$ Urban property tax (IPTU) & $\bullet \quad 50 \%$ of rural property tax & $\bullet \begin{array}{l}50 \% \text { of motor vehicle registration tax } \\
\text { (IPVA) }\end{array}$ \\
\hline - Frontage tax & $\bullet \quad 25 \%$ of the tax on industrial products (IPI) & \\
\hline
\end{tabular}

Source: Souza (nd: 11)

The local governments' source of internal revenues in Brazil includes Service tax, urban property tax and frontage tax. Service tax is levied on businesses, self-employed professionals or groups of professionals working in the same type of service (hospitals, private doctors' clinics, lawyers, estate agents etc). The federal government has provided a list of around 100 types of services which are liable to this form of taxation. Federal legislation also sets a maximum rate of $10 \%$, which can be charged for the service provided. Each municipality is free to determine the rate to be charged, varying from $0.5 \%$ to $10 \%$ of the value of the service provided and the rates have to be approved by each municipal legislature. Souza describes the service tax as the most important in absolute terms. The tax on urban property is levied on urban real estate and it is the second most important local tax nation-wide (Souza, nd). Usually size of property, location, access to services and infrastructure and other criteria are considered while determining the rate. Frontage tax is premises tax. Municipalities can also charge fees for their services and an improvement fee whenever a local public investment raises the value of a property in a specific area (Souza, nd).

The transfers that come from the states include $25 \%$ of value added tax (ICMS) and $50 \%$ of motor registration tax (IPVA). States transfer ICMS tax - value added - based on collections from each local government. Three quarters of $25 \%$ of tax value collected from a local government is transferred to the local government, while the state reserves the discretion of how to share the remaining one quarter and such discretion may include incentives for municipalities to improve on their collection. The federal government also makes some constitutional transfers to local governments. These transfers are mainly from income tax (22.5\%), rural property tax (50\%), tax on industrial products (IPI) (25\%) and tax on financial operations on gold (IPF/gold) (70\%). Souza (nd) says that municipalities that are producers of minerals, petrol and natural gas are entitled to a share of a tax collected by the federal government.

Serra and Alfonso (1999:9-10) disclose that there has been an equally important and intense process of horizontal decentralization of revenues. The concentration of federal tax revenues in the more developed regions of the country is offset by a system of federal tax sharing basically designed to benefit the less developed sub-national governmental regions. The federal transfers from income tax (IR) and from the tax on industrial products (IPI) $(22.5 \%$ and $25 \%$ respectively) make up a fund called FPM - Fundo de Participação Municipal (Municipal Participation Fund). The FPM is more or less an equalization fund. Souza posits that the FPM transfers $10 \%$ to state capitals, $86.4 \%$ to municipalities in the interior and $3.6 \%$ to municipalities with more than 156,216 inhabitants. The formula, therefore, benefits less populous municipalities. This is a plan to ensure more redistribution of resources to small and medium-sized municipalities, that is, those with greater poor population or sparsely populated local governments. The essence is to ensure fiscal balance and to blend divergent and contradictory regional differences among more and less developed regions (Serra and Alfonso, 1999: 23).

Apart from Constitutional fiscal transfers from states and federal governments, the Brazilian municipalities also receive fiscal grants or discretionary transfers from higher level governments especially the federal government as means of creating national minimum standard. The federal government uses the measure of non-constitutional (or discretionary) intergovernmental financial transfers to control state and local government spending in federally preferred service sectors, mostly health and education. The sharing of such revenues by the federal government is negotiated on a case by case basis each benefitting sub-national governments. Benefitting from such revenues is subject to signing of agreement with the Federal government; it attracts proportional spending of the sub national government's budget resources, and is subject to strict follow up and control (Castanhar, 2003). This revenue source has assumed an increasingly important place in local government financing in Brazil and thus constitutes a strong avenue to curb on the fiscal autonomy of municipalities. The table below shows a difference which the Discretionary transfers makes in the total disposable revenue of local governments from 1995 to 2002. 
Table 2: Tax Revenues Distribution by level of Government in Brazil 1995 to 2002

\begin{tabular}{|c|c|c|c|c|c|c|}
\hline & \multicolumn{3}{|c|}{ Disposable Revenues $^{1}$} & \multicolumn{3}{c|}{ Extended Disposable Revenues $^{2}$} \\
\hline & Central & States & Local & Central & States & Local \\
\hline 1995 & 61.78 & 25.98 & 12.24 & 61.78 & 25.98 & 12.24 \\
\hline 1999 & 63.31 & 23.96 & 12.74 & 59.71 & 25.05 & 15.24 \\
\hline 2000 & 62.78 & 24.51 & 12.71 & 58.71 & 25.83 & 15.46 \\
\hline 2001 & 62.60 & 24.45 & 12.95 & 58.71 & 25.82 & 15.48 \\
\hline 2002 & 63.27 & 23.72 & 13.01 & 59.43 & 25.01 & 15.57 \\
\hline
\end{tabular}

Source: Termometros Fiscais da Tributacao e da Decentralizacao (Nevember, 2002) in Castanhar (2003: 20)

Disposable revenues are the shares of each level of government's revenue after the mandatory constitutional transfers, while the Extended Disposable revenues are shares after Constitutional and Discretionary transfers. From the table, it is clear that the municipios gained close to 2.5 percent of their percentage of sharable revenues from discretionary transfers for 1999, 2.75 percent for 2000, 2.53 percent for 2001 and 2.56 percent for 2002. As noted, the discretional transfers help the federal government to control the financial expenditure and to direct policies and programmes of sub national governments to priority areas.

In Nigeria, local governments de jure share in fiscal federalism in two ways: (1) direct financial allocations from the Federation Account in the same way the federal government and states also get allocation and (2) internally generated revenues also stipulated in the federal constitution. Section 162 (3) of 1999 constitution provides that 'any amount standing to the credit of the Federation Account shall be distributed among the Federal and State Governments and the local government councils in each State on such terms and in such manner as may be prescribed by the National Assembly'. Unfortunately, the local governments do not get their allocations directly but through the states. Section 162 $(5,6,7$ and 8) of the 1999 constitution provide guidelines for making federal allocations to the local councils. Federal allocations for the local councils are first allocated to the States for the benefit of their local government councils in such manner and terms as may be prescribed by the National Assembly (162:6) through the 'State Joint Local Government Account' (162: 7) and then distributed among the local government councils of that state on such terms and in such manner as may be prescribed by the House of Assembly of the State (162:8).

Constitutional provision for other sources of internally generated revenues for local governments is to be found in the functions allocated to the local government councils. In the Second Schedule, part II (10) and Fourth Schedule of the 1999 constitution, the sources of local government internally generated revenues include tenement charges on private houses, rates, stipulated licenses, fees and fines, rents on local government properties such as market stalls and motor parks etc.

Generally, Brazil is highly rated in its fiscal intergovernmental relations and decentralisation. Serra and Alfonso (1999: 9) aver that "among developing nations, there is no doubt that Brazil has made the greatest progress in terms of autonomy.... In a grouping of ten rich and poor nations, the highest autonomy index was that of Brazil, even surpassing the United States, Germany and Canada." Despite this revelation, it is also shown that the Brazilian local governments' own sources of revenue are still less yielding. As explained by Souza (nd: 16):

The local taxation system and local taxes present several limitations. Firstly, the tax system concentrates taxation heavily on production, sales and consumption, which are not under local government jurisdiction. Secondly, local taxes urban property, services and property transfer taxes - require large registers which have to be regularly updated and the tax collector has to keep up with the property market; these taxes require the issuing of a great number of bills for its payment; and the ISS covers a wide array of service activities, in particular of small businesses. Thirdly, local taxes are not best suited for a country that home (sic) to a great number of poor people who do not have access to property and a country in which businesses are small and unstable.

Invariably, a significant portion of local governments' expendable revenues come from the transfers of the higher level governments especially the federal government. Souza discloses that both federal and states' transfers to local governments in Brazil still account for $90 \%$ of local government revenue. The implication of this is that local governments' financial capacity is very much dependent on the allocation decisions of higher order governments for as Katorobo (2005) thinks, if subnational governments own revenue accounts for only 10\% of expenditure and $90 \%$ comes from higher level governments, then the sub-national government is financially dependent on the higher level one.

In Nigeria, a large part of local government funding also come from federal allocations. The internal revenue 
sources as provided in the Second Schedule, part II (10) and Fourth Schedule of the 1999 constitution include taxes, rates, licenses, fees and fines, rents on local government properties such as market stalls and motor parks etc. The greatest problem with most of these sources as Oguonu (2007:138) remarks is that most of them are yet to be tapped in most local governments. The table below provides some trends in local government funding from various sources from 2000 to 2006.

Table 3: LGs' Finances from Federal, State and LG Sources, 2000 - 2006 (N billion)

\begin{tabular}{|c|c|c|c|c|c|c|c|}
\hline Item & 2000 & 2001 & 2002 & 2003 & 2004 & 2005 & 2006 \\
\hline Total Revenue & 147.0 & 169.2 & 169.6 & 357.9 & 453.8 & 582.0 & 659.4 \\
\hline \multicolumn{8}{|l|}{ Fed. Rev. All ${ }^{1}$} \\
\hline (a) FGN FA2 & 118.6 & 128.5 & 128.9 & 291.4 & 375.7 & 493.0 & 550.8 \\
\hline (b) FGN VAT ${ }^{3}$ & 13.9 & 20.1 & 18.7 & 39.6 & 46.0 & 55.8 & 75.9 \\
\hline (c) FGN SF4 & 5.4 & 13.0 & 9.9 & 4.6 & 6.1 & 6.0 & 6.1 \\
\hline Total FGN & 137.9 & 161.6 & 157.5 & 335.6 & 427.8 & 554.8 & 632.8 \\
\hline$\%$ & 93.8 & 95.5 & 92.9 & 93.8 & 94.3 & 95.3 & 96.0 \\
\hline State Rev. All. ${ }^{5}$ & 1.9 & 1.6 & 1.7 & 2.1 & 3.6 & 3.2 & 3.4 \\
\hline$\%$ & 1.3 & 0.9 & 1.0 & 0.6 & 0.8 & 0.5 & 0.5 \\
\hline LGs' Inter. Rev. ${ }^{6}$ & 7.2 & 6.0 & 10.4 & 20.2 & 22.4 & 24.0 & 23.2 \\
\hline$\%$ & 4.9 & 3.5 & 6.1 & 5.6 & 4.9 & 4.1 & 3.5 \\
\hline
\end{tabular}

Notes: (1)Fed. Rev. All. -Federal Revenue Allocation; (2)FGNFA; Federal Government of Nigeria, Federation Allocation; (3)FGN VAT-Federal Government of Nigeria, Value Added Tax; (4)FGNSF-Federal Government of Nigeria, Stabilization Fund; (5)State Rev. All.-State Revenue Allocation; ( 6)LGs'Inter. Rev.-Local Governments' Internal Revenue generation)

Sources: Calculated from 2003 and 2006 Central Bank of Nigeria Annual Reports and State of Accounts as cited in Imhalahimi and Ikeanyibe (2009:16)

The local governments could only generate an average of $4.65 \%$ of their finances for seven years as shown in Table 3 . The average figure may be quite deceptive as a greater part of the revenue is generated by few urban local governments while many rural local governments hardly generate $0.5 \%$ of their finances. As it stands, over $90 \%$ of local government revenues are still externally received and mainly from the federal allocations. In the table as shown, Imhalahimi and Ikeanyibe (2009) reveal that federal allocations constituted $93.8 \%$ (2000), 95.5\% (2001), 92.9\% (2002), 93.8\% (2003), $94.3 \%$ (2004), 95.3\% (2005) and 96\% (2006) of average local government total revenues in Nigeria. The above table also reveals that states contributed on the average only $0.8 \%$ of the total local government finances for the period of seven years (2000-2006).

Most challenges of local government financing come from the states. They not only fail to distribute $10 \%$ of their internally generated revenue to local governments as provided, they use the medium of State Joint Local Government Account and other Inter Governmental Relations mechanisms to intercept and interfere with federal allocations to the local governments. Some states also take over lucrative sources of revenue constitutionally allocated to local governments such as markets and motor parks management. Thus despite constitutional provisions for local government funding, Nigerian local governments remain substantially dependent on external sources. Even though federal allocations are block grants that are not attached to specific projects, the intermediate role of the states in releasing funds to local governments provide grounds for various manipulations.

\section{Concluding Remarks}

The practice of entrenching the autonomy of local governments constitutionally is becoming popular international practice. Both federal and unitary states adopt this practice. In a federation, the approach somewhat elevates the local governments to a third tier status that makes them partners to the federal contract. This practice does not necessarily guarantee de facto autonomy to the local government system. The utility of the three tier federative structure in guaranteeing local government autonomy apparently rests in the manner of power allocation in the constitution and respect for those provisions by stakeholders. When powers are granted through another tier of government than the constitution itself, the granting authority often perceives the transfer of power as a loss of its own authority (Steytler, 2005).

For the Nigerian case, the approach employed in allocating the powers of local governments is to make the 
powers/functions of local government councils inchoate without the laws of the states. The drafters of the constitution were probably concerned with avoiding the effect of strict separation of powers along vertical lines among the three tiers of government to avoid the pitfalls of dual federalism. This approach fails to realize the goal of political autonomy for the local government. The power of bringing the local government council into existence is purely a matter of state government as provided in section 7 (1), "... government of every state shall ensure their existence under a law which provides for the establishment, structure, composition, finance and functions of such councils". In most of the functions or rights of local government including the issue of fiscal allocations, it is ironical that the State House of Assembly is mentioned as the determiner of the functions or allocations despite constitutional provisions. For instance, while the local government council has power to make assessment for tenement rates, the taxes to be levied are "as may be prescribed by the House of Assembly of a state." The failure to clearly establish the powers, functions, direct access to federal allocations and other protections for local government in the constitution makes the Nigerian system more like a two tier federal structure with an embedded local government. The hullabaloo about third tier local government system in Nigeria therefore is exaggerated. As Nwabueze (1994) argued, if the state government has the constitutional power to establish local government and to define its structure and functions (which the constitution also stipulates), it clearly and necessarily implies that local government is a mere agency or creation of the state government. Rather than help realize local government autonomy, constitutionalisation of local government in the manner perfected in Nigeria, encourages conflict between the states and federal government, and competition between the states and their local governments.

The 1988 constitution of Brazil not only provides principles, rules and rights, but also a wide range of public policies for the municipalities (Souza, 2004). But this also creates problems for intergovernmental relations and control of local government system. Souza (nd) remarks that the constitutionalisation of several aspects of the country's life has resulted in tensions between the need for rapid responses to macroeconomic demands and the lengthy process of meeting these demands through constitutional change. Hence, the various amendments of the constitution in 1992, 1993, 1994, 1995, 1996, 2003 especially in the areas of (a) imposing limits on sub-national freedom to spend their resources, as a requirement of the federal policy of fiscal control (b) earmarking specific resources to be spent on health care and primary education; and (c) decreasing the amount to be freely transferred from the federal to subnational order (Souza, 2004). While Brazilian Municipalities enjoy a higher degree of political autonomy, the problem remains how to reconcile greater fiscal decentralization with national and rational economic objectives (Afonso, 2001).The 1988 constitution did not so much pay attention to economic issues such as public deficit, inflation control, fiscal adjustment and globalization (Souza, 2004), issues that constitute the macroeconomic roles of the Union government. It is therefore more practicable and flexible that constitutions should not attempt to define a detailed system permanently (Prud'homme, 2006). Rather than encourage more cooperative relations and flexibility, constitutionalisation of local government throws up hindrances that could be difficult to address without constitutional amendments.

\section{References}

Adeyemo, D.O. (2005) "Local Government Autonomy in Nigeria: A Historical Perspective", Journal of Social Sciences, 10 (2) Pp77-87

Afonso, J. R. (2006) "Decentralization and Budget Management of local Government in Brazil" retrieved on 21/01/2011 from http://info.worldbank.org/etools/docs/library/229650/Afonso.pdf

Afonso, J.R (2001) "Brazil: Fiscal Federalism, Tax Modernization and Consumption and Production Taxes", Paper Presented at International Seminar, Los Angeles, USA

Castanhar, J.C. (2003) 'Fiscal federalism in Brazil: historical trends present controversies and future challenges', Paper presented at VIII Congreso Internacional del CLAD sobre la Reforma del Estado y de la Administracion Publica, Panama, 28-31st

Chaturvedi, A.K. (2006), Dictionary of Political Science, New Delhi: Academic (India) Publishers.

Dosenrode, S. (2010) "Federalism theory and neo-functionalism: elements for an analytical framework" Perspectives on Federalism, Vol. 2, issue 3, 2010, E-1 to E.28

Elazar, D. J.(1987) Exploring Federalism, Alabama: the University of Alabama Press

Elekwa, N.N. (2009) "Achieving economic stability through intergovernmental fiscal coordination: Using fiscal responsibility Act (FRA) as framework" Journal of Politics and Administration, Vol.2, No.1 Pp1-9

Federal Republic of Nigeria (1999) COnsitution of the Federal Republic of Nigeria 1999, Lagos: Federal Government Press

Federative Republic of Brazil 1988 Constitution, with 1996 reforms in English, accessed 12 March, 2014

Friedrich, C.J. (1964) Man and His Government, New York: McGraw-Hill

Gamper, A. (2005) "A "Global Theory of Federalism": The Nature and Challenges of a Federal State", German Law Journal, Vol. 06 No. 10, Pp1297-1318

Ikeanyibe O. M. (2008) 'The constitutional third tier status of local government in Nigeria: implications for flexibility and dynamism in local governance', The Constitution: A Journal of constitutional Development, Vol. 8, No. 3, Pp 18-36

Imhalahimi, J.E. and Ikeanyibe M.O. (2009)'A review of Nigerian government's regulatory efforts to enhance local government autonomy' 
in Journal of Political Economy, Vol 3, Nos 1\& 2, Pp.1-31)

Katorobo, J. (2005) "Decentralization and local autonomy for participatory democracy", Paper read at the 6th Global Forum on Reinventing Government: Towards Participatory and Transparent Governance 24 - 27 May 2005, Seoul, Republic of Korea

Livingstone, W.S.(1985) "A note on the nature of federalism" In: J.P. Meekison. (Ed): Canadian Federalism: Myth or Reality. Toronto: Methven

Montero, A.P. (2010)'Brazil' in: Introduction to Comparative Politics $5^{\text {th }}$ ed, by Mark Kesselman, Joel Krieger, William Joseph (Eds), Boston, USA: Wadsworth Cengage Learning Pp.415-469

Nwabueze, B.O. (1994) Federalism in Nigeria under the Presidential Constitution, London: Hurst and Company

Obikeze, O.S and Obi, A. (2004) Public Administration in Nigeria: A Developmental Approach, Onitsha: Bookpoint Ltd

Obianyo, N.E. (2005) "Federalism, constitutionalism and local government system in Nigeria and the need for constitutional amendment", In: Warisu O. Alli (ed.) Political Reform Conference, Federalism and the National Question in Nigeria, The Nigerian Political Science Association

Oguonu, C. (2007) 'Comparative Analysis of local government finance in Nigeria and the United States' in Nigerian Journal of Social Sciences, Vol. 4 No 1, Pp 137-151

Prud'homme, R. (2006) "Local Government Organisation and Finance in France", Anwar Shah ed., Local Government in Industrial Countries: Public Sector Governance and Accountability Series, Washington, D.C.: The World Bank

Rosenbloom D.H and Kravchuk, R.S. (2002) Public Administration: Understanding Management, Politics and Law in the Public Sector, Boston: Mcgraw Hill

Serra, J. and Afonso, R.R. (2007) Fiscal federalism in Brazil: An overview, Cepal Review 91, 29-51

Serra J. and Afonso, J.R. (1999) 'Fiscal federalism Brazilian style: Reflections', Paper Presented at the Forum of Federations International Conference on Federalism, in Mont-Tremblant, Canada, October 6-8, 1999

Soadaro, M.J. Brown, N.J., Collinwood, D.W., Dickson, B.J. Klesner, J.L. and Sisk, T.D. (2001) Comparative Politics: A Global Introduction, Boston: McGraw-Hill Higher Education Souza Celina (2004) "Subnational constitutionalism in Brazil: Taxing, spending, and borrowing", Paper Prepared for delivery at the conference Federalism and Subnational Constitutions: Designs and Reforms. March 22-27, 2004, Bellagio, Italy, Accessed: http://camlaw.rutgers.edu/statecon/subpapers/souza.pdf

Souza, C. (1997). Constitutional Engineering in Brazil: The Politics of Federalism and Decentralization. New York: St. Martin's Press

Souza, C. (nd) 'Brazil's System of Local Government, Local Finance and Intergovernmental Relations'. This paper is part of the EngKaR Research Projet 8070: Building Municipal Capacity for Finance and Budgeting. It has been commissioned by the International Development Department of the School of Public Policy, University of Birmingham (UK), retrieved on $5^{\text {th }}$ September, 2010 from

Steytler, N. (2005) The Place and Role of Local Government in Federal Systems ed. Johanesburg: Konrad-Adenauer-Stiftung

Tukur, A. (2007) "Fiscal federalism and the taxonomy of revenue allocation: Mechanisms, conflicts and coordination" A Presentation at the Nigerian Governors' Forum Retreat, Abuja International Conference Centre

Vandamme, T. (2011) "From Federated Federalism to Harmonized Federalism: The Case of EU Subsidiarity Scrutiny in Spain and Belgium", Working Paper Series 2011 - 05 Amsterdam Centre for European Law and Governance

Wheare, K.C. (1964) Federal Government, London: Oxford University Press

Wolman, H. McManmon, R. Bell, M. and Brunori, D. (nd) "Comparing Local Government Autonomy Across States" Working Paper George Washington Institute of Public Policy Working Paper, retrieved 5/3/2014 from www.gwu.edu/ gwipp 